\title{
Proximate Composition and Antinutrient Contents of Some Common Spices in Nigeria
}

\author{
C.U. Ogunka-Nnoka ${ }^{1}$ and H.D. Mepba*, ${ }^{*}$ \\ ${ }^{I}$ Department of Chemistry, Rivers State University of Science and Technology, Port Harcourt, Nigeria \\ ${ }^{2}$ Department of Food Science \& Technology, Rivers State University of Science \& Technology, Port Harcourt, Nigeria
}

\begin{abstract}
Indigenous Nigerian spices consist of parts of trees, shrubs and grass which abound in the tropical rain forest and savannah grassland zones. They are used principally to spice foods and drinks and as medication for various ailments. Although they are important components of the diets of rural Nigerians, knowledge of their contributions to human nutrition and contents of toxicants that influence the availability of nutrients in foods is lacking and has limited their use in food. The proximate composition and contents of naturally occurring toxicants (antinutrients) of five commonly consumed Nigerian spices: 'bafilo' (Uapaca guineense), 'atarko' (Zanthoxyllus zanthoxyloides). 'amilo' (Parinari excelsa), 'uburo' (Afromomum danielli) and 'clove' (Syzygium aromaticum) were evaluated and studied. The protein, carbohydrate and lipid contents of $U$. guineense, Z. zanthoxyloides, P. excelsa, A. danielli and S. aromaticum ranged from $7.8-8.6 \%$, $67.6-68.6 \%$ and $9.3-10.8 \%$, respectively while their ash contents ranged from $1.1-1.7 \%$. U. guineense, Z. zanthoxyloides, $S$. aromaticum had highest protein, lipid and carbohydrate contents respectively while $U$. guineense had a significantly $(\mathrm{P} \leq 0.05)$ higher total ash than other spices analysed. The cyanogenic glycoside, oxalates, tannins, saponins and phytate contents of raw $U$. guineense, Z. zanthoxyloides, P. excelsa, A. danielli and S. aromaticum ranged from $3.4-$ $10.2 \mathrm{mg} / 100 \mathrm{~g}, 0.6-3.1 \mathrm{mg} / 100 \mathrm{~g}, 0.6-5.0 \mathrm{mg} / 100 \mathrm{~g}, 2.6-6.4 \mathrm{mg} / 100 \mathrm{~g}$ and $2.8-4.8 \mathrm{mg} / 100 \mathrm{~g}$ respectively. Generally, the antinutrient contents of the market samples were low and below stated levels of toxicity. Boiling and dehulling of seeds prior to pulverising and packing of spices caused significant $(\mathrm{P} \leq 0.05)$ reductions in the antinutrient contents of the processed spices. Mean reductions of $71.5 \%, 87.5 \%, 73.1 \%, 71.9 \%$ and $73.9 \%$ cyanogenic glycosides, oxalates, polyphenols, saponins and phytates in U. guineense, Z. zanthoxyloides, P. excelsa, A. danielli and S. aromaticum respectively were obtained in the processed spices. The implications of these treatments on the contents of toxicants in foods are also discussed.
\end{abstract}

Keywords: Proximate contents, cyanogenic glycosides, tannins, saponins, oxalates phytates.

\section{INTRODUCTION}

Spices consist of a collection of leaves and/or branches of plants ripened fruits or seeds or root / bulbs of certain plants that are usually dried and used to season foods because of their distinctive flavours and aromas. Indigenous spices and herbs in Nigeria are mostly obtained from the wild [1,2] and little attempt has been made to domesticate and cultivate them despite the fact that they constitute a large proportion of the daily diets of rural dwellers [3]. Ironically, Nigeria imports substantial quantities of processed exotic spices from U.S.A., U.K and France [4]. The implication is that many of these indigenous spices could become extinct due to deforestation and reluctance of people to venture into the forest to harvest them. This could explain why most of the indigenous spices such as 'bafilo' (Uapaca guineense), 'atarko' (Zanthoxyllus zanthoxyloides). 'amilo' (Parinari excelsa), 'uburo' (Afromomum danielli) and 'clove' (Syzygium aromaticum) are lacking in substantial quantities in urban markets.

*Address correspondence to this author at the Department of Food Science \& Technology, Rivers State University of Science \& Technology, Port Harcourt, Nigeria; E-mail: mepba12002@yahoo.co.uk
Indigenous spices are used generally to prepare pepper soups which are hot and spicy especially during the cold seasons. Additionally, they are very important in the post parturition diets of women, during which time it is claimed that these spices and herbs aid in uterine contraction [3]. They are used to spice drinks and in nutritionally insignificant quantities as food additives for flavouring and indirectly for their antibacterial and antioxidant properties [5,7]. Thus, given their considerably low levels of applications in foods, reports on the nutritional contributions of spices in food is scant in literature. Nwinuka et al. [8] however, reported significant variations in the moisture, crude protein, carbohydrate and ash contents of Zingiber officinale, Allium cepa var cepa and Piper guineense seeds.

Substances which occur naturally in foods manifest their toxicities especially when consumed with foods in large or little doses [9]. Some of these dietary or anti-nutritional factors interfere with the bio-availability of nutrients and constitute a major factor limiting the wider food use of such tropical plants. The presence of phytate in foods is known to lower the bioavailability of minerals and inhibits several proteolytic enzymes and amylases [10]. Similarly, cyanogenic glycosides are widely distributed in higher plants as well as in ferns, moths and insects [11]. Toxicologically significant dietary intake of cyanide result either from improper 
choice of plant variety such as some lima beans or inadequate processing as occur in cassava [12] or accidental intake as in the case of a 3 year old girl who incurred poisoning from eating approximately 15 apricot kernels containing $0.33 \%$ available cyanide [13].

Soya bean, spinach and sugar beets contain saponins which are also glycosides that cause haemolysis of erythrocytes [14]. Polyphenols such as tannins found in tea and related substances found in coffee decrease the digestibility of proteins and carbohydrates due to formation of insoluble enzyme-resistant complexes [15].

Similarly, spinach, strawberries and sesame seeds have high contents of calcium but only $5 \%$ of it can be absorbed because the vegetable has high levels of oxalic acid which binds calcium and iron in foods [9].

Because of their pleasant flavours and aroma characteristics attention has not been paid to the possible presence of toxicants in spices that are widely used in foods. However, pre-treatments such as soaking, boiling and dehulling of spices prior to drying, pulverising and packaging had been known to cause significant reductions in cyanide contents of cassava [12], polyphenols and phytate contents of dry beans [16] and tannin contents of cowpea seeds [17]. The present study was undertaken to evaluate the nutritional contributions and presence of antinutrients in some commonly consumed Nigerian spices.

\section{MATERIALS AND METHODS}

\section{Samples Source and Preparation}

Samples (20kg each) of 'bafilo' (Uapaca guineense), 'atarko' (Zanthoxyllus zanthoxyloides). 'omilo' (Parinari excelsa), 'uburo' (Afromomum danielli) and 'clove' (Syzygium aromaticum) were purchased from local farmers from Ughelli at the Fruit Garden Market in Port Harcourt, Nigeria. Samples $(500 \mathrm{~g}$ each) were sorted and cleaned to remove rotten seeds and debris then washed and boiled $\left(100^{\circ} \mathrm{C}\right)$ in distilled water in ratio of $1: 10(\mathrm{w} / \mathrm{v})$ seed to water for $60 \mathrm{mins}$. The seeds were allowed to cool at room temperature then dehulled and oven-dried at $60^{\circ} \mathrm{C}$ for $12 \mathrm{hrs}$.

In another experiment, the partially dried raw seeds procured were cleaned as above and similarly oven-dried but without dehulling. U. guineense, P. excelsa, and S. aromaticum were sliced into about $2 \mathrm{~cm}$ thick pieces prior to being dried to facilitate rate processes. Dried samples were separately ground in a Kenwood Food Processor, Model 967, England, then sieved to $300 \mathrm{~mm}$ mesh. Ground spices were packaged in sealed low density polythene bags and stored in two desiccators for subsequent analysis.

\section{CHEMICAL ANALYSIS}

Proximate analysis for moisture (Method 14:004), crude protein (Method 2.057), Lipid (Method 7.062), Crude Fibre (Method 7.070) and total ash (Method 14.006) were determined according to AOAC [18] methods. Total available carbohydrate was analysed using Clegg-Anthrone reagent method of Osborne and Voogt [19].

Cyanogenic glycoside contents of sample were determined by alkaline titration method [18]. Briefly, samples (1.0g each in triplicate) dissolved in $200 \mathrm{ml}$ distilled water were distilled for $2 \mathrm{hr}$ to collect $150 \mathrm{~cm}^{3}$ of distillate. To the distillate, was added $20 \mathrm{~cm}^{3}$ of a $2.5 \% \mathrm{NaOH}$ and the volume made up to $250 \mathrm{~cm}^{3}$. To samples $\left(100 \mathrm{~cm}^{3}\right.$ of diluted distillate) was added $8.0 \mathrm{~cm}^{3}$ of $6 \mathrm{M} \mathrm{NH} \mathrm{NH}_{4} \mathrm{OH}$ solution and $2.0 \mathrm{~cm}^{3}$ of $5 \% \mathrm{KI}$, then titrated against $0.02 \mathrm{M} \mathrm{AgNO}$ solution using a $10 \mathrm{~cm}^{3}$ microburette. The end-point was noted as a permanent turbidity against a black background. Titre values were obtained and cyanogenic glycoside contents calculated using the formula.

Cyanogenic glycoside $\mathrm{mg} / 100 \mathrm{~g}=\frac{T V \times 1.08 \times E V}{S M \times A L} \times 100$

Where:

TV

EV

SM

$\mathrm{AL}$

$$
\begin{array}{ll}
= & \text { Titre value }\left(\mathrm{cm}^{3}\right) \\
= & \text { Extract vol. }\left(\mathrm{cm}^{3}\right) \\
= & \text { Sample Mass }(\mathrm{g}) \\
= & \text { Aliquot }\left(\mathrm{cm}^{3}\right) \text { used } .
\end{array}
$$

$\mathrm{N} / \mathrm{B} 1 \mathrm{~cm}^{3}$ of $0.02 \mathrm{~N} \mathrm{AgNO}_{3}=1.08 \mathrm{mg} \mathrm{HCN}$.

Phytic acid contents were determined by the method of Davis and Reld as modified by Abulude [20]. Briefly, finely ground samples $\left(8.0 \mathrm{~g}\right.$ each) were dissolved in $200 \mathrm{~cm}^{3}$ of a $2 \% \mathrm{HCl}$ by shaking the solution for $3 \mathrm{hr}$. The solution was filtered and $10 \mathrm{~cm}^{3}$ of $0.3 \% \mathrm{NH}_{4} \mathrm{SCN}$ added to $50 \mathrm{~cm}^{3}$ of filtrate followed with $107 \mathrm{~cm}^{3}$ distilled water for proper acidity. This was titrated against $0.00195 \mathrm{~g} / \mathrm{cm}^{3}$ Ferric chloride solution until a brownish yellow colour persisted.

\section{Calculation}

Phytate phosphorus $=$ Iron equivalent $\times 1.95 \mathrm{~g}$ of titre

Phytate $\quad=$ Phytate phosphorus $x 3.65 \mathrm{~g}$

Tannin content of samples was determined by the method of Folin-Dennis as described by Pearson [21]. The method described by Munro and Bassir [22] was used for analysis of oxalate contents of samples. Briefly, $1.0 \mathrm{~g}$ each of ground spice (in triplicate) was extracted thrice by warming $\left(50^{\circ} \mathrm{C}\right)$ and stirring with a magnetic stirrer for $1 \mathrm{hr}$ with $0.3 \mathrm{M} \mathrm{HCl}$. The combined extracts were diluted to $100 \mathrm{~cm}^{3}$ with water and used for total oxalate estimation.

For oxalate estimation, $5.0 \mathrm{~cm}^{3}$ of each extract was made alkaline with $1.0 \mathrm{~cm}^{3}$ of $5.0 \mathrm{M} \mathrm{NH} \mathrm{N}_{4} \mathrm{OH}$. This was then made acid to phenolphthalein ( 2 or 3 drops was added) by dropwise addition of glacial acetic acid. A $1.0 \mathrm{~cm}^{3}$ of $5 \% \mathrm{CaCl}_{2}$ was then added and the mixture allowed to stand for 3 mins after which it was centrifuged at 3000 revolution per minute for 15 mins. The supernatant was discarded and precipitates washed thrice with hot water with thorough mixing and centrifuging each time. Then to each tube $2.0 \mathrm{~cm}^{3}$ of $1.5 \mathrm{M}$ $\mathrm{H}_{2} \mathrm{SO}_{4}$ was added and the precipitate dissolved by warming in a water bath $\left(70-80^{\circ} \mathrm{C}\right)$. The content of each tube was then titrated with freshly prepared $0.05 \mathrm{M}$ standardized $\mathrm{KMNO}_{4}$ solution till a faint pink colour appeared throughout the solution and was allowed to stand until the solution was colourless. The solution was then warmed to $70^{\circ} \mathrm{C}-80^{\circ} \mathrm{C}$ and titration continued until pink colour persisted for at least 30 seconds. Oxalate content was calculated from the formula. 


$$
\begin{array}{ll}
\text { Calcium oxalate }(\%) & =\frac{\operatorname{Mex}}{M s} \times 100 \\
\text { Where Mex } & =\text { mass of extract }(\mathrm{g}) \text { and } \\
\text { Ms } & =\text { mass of sample used }(\mathrm{g})
\end{array}
$$

The saponin contents of samples was determined following the AOAC [18] method. Saponin extraction was done using acetone and methanol. Crude lipid content of samples was extracted with acetone while methanol was used to extract saponin.

Samples (2.0g in triplicate) were folded in a filter paper and put in a thimble and extracted by refluxing in a soxhlet extractor. Extraction was done with acetone in a $250 \mathrm{~cm}^{3}$ capacity round bottomed flask for $3 \mathrm{hr}$ after which the apparatus was dismantled and another $150 \mathrm{~cm}^{3}$ capacity flask containing $100 \mathrm{~cm}^{3}$ methanol was fitted to the extractor and extraction sustained for another $3 \mathrm{hr}$.

Weight of flask before and after the second extraction was taken to note the change in weight. Methanol was recovered by distillation after the second extraction and the flasks oven-dried, allowed to cool at room temperature and weighed. Saponin content was calculated from the formula:

$$
\begin{array}{ll}
\text { Saponin }(\mathrm{mg} / 100 \mathrm{~g}) & =\frac{A-B}{S m} \times 100 \\
\text { Where A } & =\text { mass of flask and extract } \\
\mathrm{B} & =\text { mass of empty flask } \\
\mathrm{Sm} & =\text { sample mass }
\end{array}
$$

\section{STATISTICAL ANALYSIS}

A Completely Randomised Block Design (CRBD) of means of proximate composition and antinutritional factors were analysed statistically using Analysis of Variance (ANOVA) as described by Wahua [23].

\section{RESULTS AND DISCUSSIONS}

The identities, uses and specific applications of the local spices investigated are given in Table 1. The species were identified by their traditional names indicative of their rural origin. Their main sources had been the equatorial rain forest and savannah grassland. They were mainly sourced from trees or shrubs and a few from grass such_as bulbs. Many of the local spices already reported $[6,7,24]$ are difficult to source in the open markets because they are obtained from the wild where they are going into extinction due to the menace of deforestation and reluctance of people to cultivate / domesticate or venture into the forest to harvest them.

Table 1 also showed that the spices were either for spicing food and drinks or for their medicinal value. This underlines the importance of these spices in rural communities in Africa where herbal medication is popular among the low income. Kupoluyi and Ajayi [24] investigating the consumption pattern of local spices in Nigeria reported that three major use areas of; food, drink and locally prepared medications were identified by respondents. They concluded that the low and middle income groups were higher consumers of the local spices than those in the high income bracket.

Data in Table 2 gives the proximate composition of processed spices. The protein, lipid and carbohydrate contents of $U$. guineense, Z. zanthoxyloides, P. excelsa, A. danielli and $S$. aromaticum ranged from $7.8-8.6 \%, 9.3-10.8 \%$ and 67.6 $-68.6 \%$ respectively.

U. guineense, Z. zanthoxyloides and S. aromaticum had significantly $\mathrm{P} \leq 0.05$ higher protein, lipid and carbohydrate respectively than other spices analysed. No significant difference $(\mathrm{P}>0.05)$ was observed in the total ash contents of $Z$. zanthoxyloides, $P$. excelsa and $A$. danielli. The highest value

\begin{tabular}{|c|c|c|c|c|}
\hline Botanical Name & $\begin{array}{l}\text { Common and Tradi- } \\
\text { tional Name }\end{array}$ & Plant type and Habitat & Uses & Specific application \\
\hline Uapaca guineense & $\begin{array}{l}\text { aboemido (Yr), Obia } \\
\text { (lb). Bafilo (Del). }\end{array}$ & $\begin{array}{l}\text { Tree. In tropical rain forest. Fruits are } \\
\text { conspicuously warted, globose about } \\
2.5 \mathrm{~cm} \text { in diameter. An edible spice. }\end{array}$ & $\begin{array}{l}\text { Spicing, } \\
\text { medicinal }\end{array}$ & $\begin{array}{l}\text { In pepper soup, traditional soups, for } \\
\text { medicinal uses e.g. fever, post natal } \\
\text { womb congetion. In spicing vegetable } \\
\text { extracts used as beverages. }\end{array}$ \\
\hline $\begin{array}{l}\text { Zanthoxyllus } \\
\text { zanthoxyloides }\end{array}$ & $\begin{array}{c}\text { fasa kwari }(\mathrm{Ha}) \text { ata }(\mathrm{Yr}) \text {. } \\
\text { Ujo }(\mathrm{Ij})\end{array}$ & $\begin{array}{l}\text { A shrub, about } 12 \mathrm{~m} \text { tall in savannah } \\
\text { grassland. Fruits are about } 6 \mathrm{~mm} \text { long with } \\
\text { brown seed coat. }\end{array}$ & $\begin{array}{l}\text { Spicing, } \\
\text { medicinal }\end{array}$ & $\begin{array}{l}\text { In pepper soup and stews. Relief for } \\
\text { fever and constipation, and stomach } \\
\text { ache. }\end{array}$ \\
\hline Parinari excelsa & $\begin{array}{l}\text { Yirrinyinrin (yr), dee } \\
\quad \text { (Ij), Omilo (Del) }\end{array}$ & $\begin{array}{c}\text { Tree, about } 30 \mathrm{~m} \text { tall in rain forest. Drupe } \\
\text { fruits are ellipsoidal and about } 3.5 \mathrm{~cm} \\
\text { long. }\end{array}$ & $\begin{array}{l}\text { Spicing, } \\
\text { medicinal }\end{array}$ & $\begin{array}{l}\text { In traditional soups. Relief for fever } \\
\text { and stomach ache. }\end{array}$ \\
\hline Afromomum danielli & Uburo (Yr), Urima (Ib) & $\begin{array}{l}\text { A shrub in the savannah grass land. The } \\
\text { spices are tiny seeds with brown coats. }\end{array}$ & Spicing & $\begin{array}{l}\text { In traditional soups and stews. Also } \\
\text { used in vegetable extract beverages. }\end{array}$ \\
\hline Syzygium aromaticum & $\begin{array}{l}\text { Clove }(\text { E), kanafuru } \\
(\text { Yr }), \text { Kanaferi }(\mathrm{Ha})\end{array}$ & $\begin{array}{l}\text { Bulb that grows as grass at the savannah } \\
\text { grassland. Similar to garlic cloves with } \\
\text { pungent odour. }\end{array}$ & Spicing & $\begin{array}{l}\text { In soups, pepper soup, beef, poultry } \\
\text { stews and soup. }\end{array}$ \\
\hline
\end{tabular}
of all the parameters analysed was total carbohydrate composition which ranged from $67.6 \%$ in $P$. excelsa to $68.6 \%$ in $S$. aromaticum. Our result corroborates the reports of Nwinuka et al. [8] on the proximate contents of selected spices. Similarly Anuna and Obomanu [25] reported signifi-

Table 1. Identities of Local Spices and their Uses

$\mathrm{Yr}=$ Yoruba, $\mathrm{Ha}=$ Hausa, $\mathrm{Ib}=$ Igbo, Del = Delta, $\mathrm{Ij}=\mathrm{Ijaw}, \mathrm{E}=$ English. 
Table 2. Proximate Composition of Processed Spices

\begin{tabular}{|c|c|c|c|c|c|c|}
\hline Samples & Moisture (\%) & Protein (\%) & Lipid (\%) & $\begin{array}{c}\text { Total } \\
\text { carbohydrate (\%) }\end{array}$ & Crude fibre (\%) & Total ash (\%) \\
\hline \hline U. guineense & $11.2^{\mathrm{b}} \pm 0.2$ & $8.6^{\mathrm{d}} \pm 0.1$ & $9.5^{\mathrm{b}} \pm 0.2$ & $68.2^{\mathrm{c}} \pm 0.3$ & $0.8^{\mathrm{a}} \pm 0.1$ & $1.7^{\mathrm{c}} \pm 0.1$ \\
\hline Z. zanthoxyloides & $10.9^{\mathrm{a}} \pm 0.3$ & $7.8^{\mathrm{a}} \pm 0.2$ & $10.8^{\mathrm{e}} \pm 0.3$ & $67.8^{\mathrm{b}} \pm 0.2$ & $1.3^{\mathrm{b}} \pm 0.1$ & $1.4^{\mathrm{b}} \pm 0.1$ \\
\hline P. excelsa & $11.1^{\mathrm{b}} \pm 0.2$ & $8.1^{\mathrm{b}} \pm 0.3$ & $10.6^{\mathrm{d}} \pm 0.2$ & $67.6^{\mathrm{a}} \pm 0.3$ & $1.1^{\mathrm{b}} \pm 0.1$ & $1.5^{\mathrm{b}} \pm 0.1$ \\
\hline A. danielli & $11.4^{\mathrm{c}} \pm 0.1$ & $8.4^{\mathrm{c}} \pm 0.2$ & $9.7^{\mathrm{c}} \pm 0.1$ & $67.9^{\mathrm{b}} \pm 0.2$ & $1.2^{\mathrm{b}} \pm 0.1$ & $1.1^{\mathrm{b}} \pm 0.1$ \\
\hline S. aromaticum & $12.1^{\mathrm{e}} \pm 0.3$ & $7.8^{\mathrm{a}} \pm 0.2$ & $9.3^{\mathrm{a}} \pm 0.1$ & $68.6^{\mathrm{d}} \pm 0.2$ & $1.1^{\mathrm{a}} \pm 0.1$ \\
\hline
\end{tabular}

Values are means \pm S.D of three sample determinations. Means in the same columns not followed by the same superscripts differ significantly (P $\leq 0.05$ ).

cantly higher carbohydrate than other nutrient components of spices that were analysed. The variations in composition of spices analysed could be attributed to differences in agronomic factors such as variety, maturity, cultural practices as well as processing conditions [26]. Lack of knowledge of the contributions of spices to human nutrition has limited their use as flavourants in foods. According to Achinewhu [3] spices constitute a large proportion of the diets of rural dwellers and bearing essential and non-essential oils [26] as well as fatty acids, minerals and vitamins [27].

The antinutrient contents of raw, boiled and dehulled seeds of spices analysed are presented in Table 3. Boiling and dehulling of seeds caused significant $(\mathrm{P} \leq 0.05)$ reductions in the cyanogenic glycoside, oxalate, tannins, saponins and phytate contents of the processed spice samples. The cyanogenic glycoside contents of raw $U$. guineense, $Z$. zanthoxyloides, $P$. excelsa, A. danielli and $S$. aromaticum ranged from 3.4-10.2 mg/100g. Significant variations $(\mathrm{P} \leq 0.05)$ were observed in cyanogenic glycoside contents of the raw spices with highest levels in $U$. guineense. Boiling and dehulling of seeds resulted in reduction of $70.6-76.5 \%$ cyanogenic glycosides in the treated samples. The hydrocyanic acid contents of raw spices studied were significantly lower than values of $109 \mathrm{mg} / \mathrm{kg}$, and $1750 \mathrm{mg} / \mathrm{kg}$ reported in mango seed kernel and rubber seeds respectively [28,29] as well as the values reported for Delonix regia (flame of the forest) seed [30]. The values reported here falls within the range reported for raw vegetable cowpea seed [11]. Boiling generally reduced the hydrocyanic acid content as shown by our results and supported by reports in literature $[30,17]$.

Reduction of HCN in boiled and dehulled seeds may be due to vaporization of free cyanide by heat. Besides, both free and bound cyanide are water soluble and may be leached out during boiling of samples in water. Similarly, during fermentation of starch, vegetables such as cassava and maize, Corynebacterium sp. in the ferment hydrolyze starch and initiate lactic acid production. The increased acidity promotes growth of Geotrichum sp. and releases gaseous

Table 3. Antinutrient (mg/100g) Contents of Raw, Boiled and Dehulled Seeds

\begin{tabular}{|c|c|c|c|c|c|c|}
\hline$U$. guineense & $\begin{array}{c}\text { Raw } \\
\text { boiled and } \\
\text { dehulled }\end{array}$ & $\begin{array}{c}10.2^{\mathrm{f}} \\
3.0^{\mathrm{b}}(70.6)\end{array}$ & $\begin{array}{c}3.1^{\mathrm{c}} \\
0.3^{\mathrm{a}}(90.3)\end{array}$ & $\begin{array}{c}5.0^{\mathrm{d}} \\
0.4^{\mathrm{a}}(92.0)\end{array}$ & $\begin{array}{c}6.4^{\mathrm{f}} \\
1.6^{\mathrm{b}}(75.0)\end{array}$ & $\begin{array}{c}4.8^{\mathrm{f}} \\
1.3^{\mathrm{ab}}(72.9)\end{array}$ \\
\hline P. excelsa & $\begin{array}{c}\text { Raw } \\
\text { boiled and } \\
\text { dehulled }\end{array}$ & $\begin{array}{c}9.4^{\mathrm{e}} \\
2.6^{\mathrm{b}}(72.3)\end{array}$ & $\begin{array}{c}3.2^{\mathrm{c}} \\
0.3^{\mathrm{a}}(90.6)\end{array}$ & $\begin{array}{c}1.8^{\mathrm{c}} \\
0.5^{\mathrm{a}}(72.2)\end{array}$ & $\begin{array}{c}5.8^{\mathrm{e}} \\
1.8^{\mathrm{b}}(69.0)\end{array}$ & $\begin{array}{c}4.2^{\mathrm{e}} \\
1.2^{\mathrm{ab}}(71.4)\end{array}$ \\
\hline S. aromaticum & $\begin{array}{c}\text { Raw } \\
\text { boiled and } \\
\text { dehulled }\end{array}$ & $\begin{array}{c}3.4^{\mathrm{bc}} \\
0.8^{\mathrm{a}}(76.5) \\
\mathrm{LSD}=0.58\end{array}$ & $\begin{array}{c}1.6^{\mathrm{b}} \\
0.2^{\mathrm{a}}(87.5)\end{array}$ & $\begin{array}{c}0.6^{\mathrm{a}} \\
0.1^{\mathrm{a}}(83.3)\end{array}$ & $\begin{array}{c}2.6^{\mathrm{c}} \\
0.8^{\mathrm{a}}(69.2)\end{array}$ & $\begin{array}{c}3.6^{\mathrm{d}} \\
1.0^{\mathrm{a}}(72.2)\end{array}$ \\
\hline
\end{tabular}

Values are means of three sample determinations. Means in the columns not followed by the same superscripts differ significantly (P $\leq 0.05)$. Data in parenthesis are percentage reductions in concentrations of antinutrients in processed spices. 
hydrogen cyanide by hydrolysis of cyanogenic glycosides in the substrate [31]. The oxalate contents of raw $U$. guineense, Z. zanthoxyloides, $P$. excelsa, A. danielli and S. aromaticum ranged from $0.6-3.1 \mathrm{mg} / 100 \mathrm{~g}$. Boiling and dehulling of seeds caused $85.7-90.6 \%$ reductions in the oxalic acid contents of the processed spices. The oxalate content of the raw spices $(0.6-3.1 \mathrm{mg} / 100 \mathrm{~g})$ were significantly lower than those reported by Dommang et al. [32] for eight vegetables $(6.90 \mathrm{~g} / 100 \mathrm{~g}-13.90 \mathrm{~g} / 100 \mathrm{~g}$ dry matter) and are unlikely to pose health problems to consumers of the spice. Significantly lower contents of oxalate $(0.03 \mathrm{~g} / 100 \mathrm{~g}-10 \mathrm{~g} / 100 \mathrm{~g})$ had been reported for some Nigerian spices [8] and vegetable cowpea [17]. Certain species of plants are known to contain large amounts of oxalate mainly as the soluble sodium or potassium salts or the insoluble calcium salts. Reductions in oxalic acid contents of treated spices could be attributed to leaching of the acids due to the solubility of the neutral salts such as $\mathrm{Na}$ and $\mathrm{K}$ in water. The calcium salt is insoluble at neutral or alkaline $\mathrm{pH}$ but soluble in acid. The insolubility of calcium oxalate occasioned many studies [22] of the significance of ingestion of plant oxalates on calcium absorption and of the possibility that calcium deficiency might result from oxalate content of foods. It has been reported [33] that some of the anti-nutritional and off-flavour problems (bitter and astringent taste and scratches in the mouth and throat) associated with cocoyam are caused by calcium oxalate (raphids). Dietary oxalate has been known to complex with calcium, magnesium and iron leading to the formation of insoluble oxalate salts and resulting in oxalate stone [9]. However, since the raw spices had significantly low oxalate contents below the toxic levels of $2-5 \mathrm{~g}$ stated by Munro and Bassir [22], Nigerian spices would be safe for consumption after processing.

The tannin contents of the raw spices ranged from $0.6-$ $5.0 \mathrm{mg} / 100 \mathrm{~g}$. Boiling caused significant $(\mathrm{P} \leq 0.05)$ reductions $(83.3-90.6 \%)$ in tannin content of processed spices. The low tannin content of the spices could be responsible for the absence of bitter taste in the samples. Similarly Udensi et al. [17] reported that boiling vegetable cowpea for 60mins in distilled water and autoclaving for $60 \mathrm{~min}$ resulted in $75 \%$ and $62.5 \%$ tannin reduction, respectively. Reduction in tannin contents of Nigerian spices during boiling and dehulling might be attributed to the fact that tannins are polyphenols and all polyphenolic compounds are water soluble in nature [15]. Thus reduction in tannin contents may be attributed to leaching out of phenols into the cooking medium under the influence of the concentration gradient [34]. The reductions in polyphenols and other dietary factors suggest that polyphenols and other dietary factors are mostly concentrated in the seed coat, and this view is supported by other workers [16]. Paramjiyothi and Mulimani [15] reported significant reductions in dehulled and cooked redgram. They reported gradual loss when cooking time was increased from 10 to $120 \mathrm{~min}$. Desphande et al. [16] have reported that soaking prior to cooking and dehulling, further increased loss of polyphenols. It has been suggested $[15,35]$ that the apparent decrease in polyphenol levels during cooking was most likely not due to an actual loss of polyphenols but to a change in their solubility or chemical reactivity. Thus, the observed decrease may be due to binding of polyphenols with other organic substances and proteins or from alterations in the chemical structure of polyphenols [35].
The saponin levels in the spices studied are low to cause deleterious effects. Raw spice samples contained between $2.6-6.4 \mathrm{mg} / 100 \mathrm{~g}$ saponins. Boiling and dehulling of seeds caused significant $(\mathrm{P} \leq 0.05)$ reductions in saponin contents of samples. This was expected. Being glycosides, they are soluble in water and reductions in the concentrations accomplished by boiling of seeds in water and dehulling. Saponins have been shown to possess both beneficial (cholesterollowering) and deleterious (cytotoxic; permeabilization of the intestine) properties [36,37]. Although some saponins have been shown to be highly toxic under experimental conditions, acute poisoning is relatively rare both in animals and man [38].

Phytate contents of raw spice samples ranged from $2.8-$ $4.8 \mathrm{mg} / 100 \mathrm{~g}$. Following boiling and dehulling of samples, reductions of $71.4-78.6 \%$ phytate was achieved in the processed samples. The values of phytic acid in the spices were low to be of any nutritional concern when compared with values of $8.0-9.9 \mathrm{~g} / \mathrm{kg}$ dry matter reported in cereals [39]. A mean phytate loss of $73.9 \%$ was obtained in the boiled and dehulled spices. Similar losses of phytic acid $(68.5 \%)$ in Mucuna solanie [40] and $74.1 \%$ loss in vegetable cowpea, Sesquipedalis seeds [17] had been reported. Besides, roasting was reported to account for up to $65.6 \%$ reductions of phytate contents of vegetable cowpea [17]. Thus, reduction of phytate by boiling could be due to the heat labile nature of phytic acid. The apparent reduction in phytic acid contents of processed spices could be attributed to the formation of insoluble complexes such as phytic-protein and phytate-mineral complexes.

Phytate plays a significant role in the decreasing the bioavailability of multivalent cations such as $\mathrm{Ca}^{2+}, \mathrm{Mg}^{2+}, \mathrm{Zn}^{2+}$, $\mathrm{Fe}^{2+}$ and $\mathrm{Fe}^{3+}[40]$ by forming insoluble metal complexes and rendering them unavailable to man and animals. Processes such as germination, soaking, dehulling, cooking, fermentation and other autolytic treatments are known to reduce and/or eliminate phytate in foods.

\section{CONCLUSION}

The proximate composition and antinutrients (toxicants) in five commonly consumed spices in Nigeria: Uapaca guineense, Zanthoxyllus zanthoxyloides, Parinari excelsa, Afromomum danielli and Syzygium aromaticum have been evaluated. The spices had moderate protein and lipid contents and good source of carbohydrate. The ash contents suggest that they are good sources of minerals that could be available as their content of dietary factors were generally low. The significant $(\mathrm{P} \leq 0.05)$ reductions in contents of cyanogenic glycosides, oxalates, tannins, saponins and phytates with boiling and dehulling of seeds suggest that the toxicants were soluble in water and concentrated in the seed coat. Thus processing of raw spices is recommended for reduction of their toxic components and enhanced nutrient utilisation.

\section{REFERENCES}

[1] Abib A. Spices from wild Spore. A bimonthly bulletin of the technical Centre for Agricultural and Rural co-operation (CTA) France, 1994; 6 .

[2] Ogunyemi S. Disappearing spice of Southern Nigeria. In: Lost crops of Nigeria: Implications for food security. Proceedings: $3^{\text {rd }}$ Ann. Conf. of Lost Crops of Nigeria. University of Agriculture, Abeokuta, Okojie JA and Okah DU, Eds. 1992; 146-153. 
[3] Achinewhu SC. Plants: Man's Prime Necessity of Life. A Professorial Inaugural Lecture. Rivers State University of Science and Technology, Port Harcourt, Nigeria, 1996; 12-16.

[4] FOS. Federal office of statistics. Import report on spices. 1993; 4260.

[5] Wikipedia, the free Encyclopedia http://en.wikipedia.org/wiki:/ spice/2004.

[6] Achinewhu SC, Ogbonna CC, Hart AD. Chemical composition of indigenous wild herbs, spice, fruits, nuts and leafy vegetables used as foods. Plant Foods Hum Nutr 1994; 58: 9-14.

[7] Farinu TD. Chemical composition of some plant products of the forest zone of Nigeria. Food Chem 1986; 22: 315-320.

[8] Nwinuka NM, Ibe GO, Ekeke GI. Proximate composition and levels of some toxicants in four commonly consumed spices. J Appl Sci Env Manag 2005; 9: 150-155.

[9] Wardlaw GM, Kessel MW. Perspectives in Nutrition, $5^{\text {th }}$ ed. 2002; 469-779. Mcgraw-Hill Companies Inc. New York.

[10] Singh M, Krikorian HD. The inhibition of trypsin and phytate. J Agric Food Chem 1996; 32: 779.

[11] Liener IE. Toxic constituents of plant foodstuff. Academic Press. New York. 1986; 144.

[12] William AV, Osuntokun BO. Peripheral neuropathy in tropical nutritional ataxia in Nigeria. Trop Geogr Med 1996; 22: 281-285.

[13] Hall RL. Cyanogenic glycosides In: Toxicants occurring Naturally in Foods. Committee on food protection, FNB, Natural Academy of Science, Washington DC. 1975; 299-308.

[14] ADA. American Dietetic Association. Functional Foods J Am Diet Association 2000; 99-128.

[15] Paramjyothi S, Mulimani VH. Effect of sprouting, cooking and dehulling on polyphenols of redgram (Cajanus cajan L). J Food Sci Tech 1996, 33: 259-260.

[16] Desphande SS, bathe SK, Comforth DP and Salunkhe DK. Effect of dehulling on phytic acid, polyphenols and enzyme inhibitors of dry beans (Phaseolus vulgaris, L.) J Food Sci 1990; 47:1846-1847.

[17] Udensi EA, Ekwu FC, Isonguzo JN. Antinutrient factors of vegetable cowpea (sesquipedalis) seeds during thermal processing. Pakistan J Nutr 2007; 2: 194-197.

[18] AOAC. Official Methods of Analysis. Association of Official Analytical Chemists, $16^{\text {th }}$ ed. Washington DC. 1995.

[19] Osborne DR, Voogt P. The Analysis of Nutrients in Food. Academic Press, London. 1978; 134-154.

[20] Abulude FO. Effect of processing on nutritional composition, phytate and functional properties of rice (Oryza sativa) flour. Nigerian Food J 2004; 22: 97-104.

[21] Pearson D. The Chemical Analysis of Food. Churchill, Livingstone, Edingburgh, London. 1976; 352-353.

[22] Munro A, Bassir O. Oxalate in Nigerian vegetables. W African J Biol Appl Chem 1980; 12:14 -18.

[23] Wahua TAT. Applied Statistics for Scientific Studies. Africa Link Press, Aba, Nigeria, 1999; 68-76.
[24] Kupoluyi CF, Ajayi TO. Consumption pattern of local spices in Nigeria. Nigerian Food J 2002; 20: 41- 46.

[25] Anuna MI, Obomanu F. Proximate composition of eight local spices. Proceedings: $23^{\text {rd }}$ Ann. Conf. of the Nigerian Institute of Food Science and Technologists (NIFST), Raw Material Research and Development Council) Abuja, Nigeria 2000; 295-297.

[26] Meadows AB, Farmer LJ, Graham WD. Superficial fluid and solvent extraction of two varieties of Nigerian ginger (Zingiberis officinale roscoe) at various stages of maturity. Nigerian Food J 2002; 20: 65-68.

[27] Meadows AB, Morris I, Olorunda AO and Aina TO. The size localization of yellow pigmented lipid cells 6-gingerol in two varieties of Nigerian ginger (Zingiberis officinale roscoe) at various maturity stages. Nigerian Food J 2004; 22: 23-28.

[28] Ravindran V, Sivakanesans R. The nutritive value of mango seed kernel for starting chicks. J Sci Food Agr 1996; 71: 245-250.

[29] Ravindran V, Ravindran G. Some nutritional and anti-nutritional characteristics of para-rubber (Hevea brasiliensis). Food Chem 1988; 30: 93-102.

[30] Abdulahi SA, Abdulahi GM. Effect of boiling on the proximate, antinutrients and amino acid composition of raw Delonix regia seeds. Nigerian Food J 2005; 23: 128-132.

[31] Fellows P. Fermentation and Enzyme Technology. In: Food Processing Technology, Principles and Practice $\left(2^{\text {nd }}\right.$ ed.) Ellis Horwood Limited, Chichester, West Sussex, UK. 1999; 178-180.

[32] Dommang F, Eka OU, Fokou E. Nutrient composition of some leafy vegetables eaten in Cameroon. (1). Evaluation of sugars, crude fat, minerals and oxalic acid. Nigerian J Nutr Sci 1990; 8: 87103

[33] Okaka JC. Handling, Storage and Processing of Plant Foods. OCJ Academic Publishers, Enugu, Nigeria. 2005; 5, 10-13.

[34] Vijayakumani K, Siddhuraju P, Janadhan K. Effect of domestic processing on the levels of certain antinutrients in Prosopsis chilensis. Food Chem 1992; 59 367-370.

[35] Ekpeyong TF. Effect of cooking on polyphenol contents of some Nigerian Legume and cereals. Nutr Rep Int 1998; 31: 561.

[36] Price KR, Johnson IT, Fenwick GR. The Chemical and Biological Significance of Saponins in Foods and Feedstuffs. CRC Crit Rev Food Sci Nutr 1987; 26: 27-135.

[37] Oakenful D, Sidhu GS. Saponins In: Cheeke PR, Ed. Toxicants of Plant Origin. Academic Press, New York. 1989; 2: 78-113.

[38] Osagie AU. Anti-nutritional Factors In: Osagie AU, Eka OU, Eds. Nutritional Quality of Plant Foods Post Harvest Research Unit, Dept. of Biochemistry, University of Benin, Benin City, Nigeria. 1988; 221-224.

[39] Ravindran V, Ravindran G, Sivakakagan R. Total and phytic phosphorus contents of various foods and feedstuffs of plant origin. Food Chem 1994; 50: 133-136.

[40] Reddy NR, Salunkhe DK. Effect of fermentation on phytate phosphorus and mineral content of black gram and rice blends. J Food Sci 1995; 45: 1709-1715. 